\title{
Growth of cactus pear cv. Miúda under different salinity levels and irrigation frequencies
}

\author{
JOELMA DE L. FREIRE ${ }^{1}$, MÉRCIA VIRGINIA F. DOS SANTOS ${ }^{1}$, JOSÉ CARLOS B. DUBEUX \\ JÚNIOR ${ }^{2}$, EGÍDIO BEZERRA NETO ${ }^{1}$, MÁRIO DE A. LIRA ${ }^{3}$, MÁRCIO V. DA CUNHA ${ }^{1}$, DJALMA \\ C. DOS SANTOS ${ }^{3}$, SILVANIA O. DE AMORIM ${ }^{1}$ and ALEXANDRE CARNEIRO L. DE MELLO ${ }^{1}$ \\ ${ }^{1}$ Universidade Federal Rural de Pernambuco, Departamento de Zootecnia, Rua Manoel \\ de Medeiros, s/n, Dois Irmãos, 52171-900 Recife, PE, Brazil \\ ${ }^{2}$ University of Florida, North Florida Research \& Education Center, 3925, Highway 71, Marianna-FL, USA \\ ${ }^{3}$ Instituto Agronômico de Pernambuco, Avenida General San Martin, 1371, Bongi, 50761-000 Recife, PE, Brazil
}

Manuscript received on January 22, 2018; accepted for publication on July 7, 2018

\begin{abstract}
Soil and water salinity are considered the main limiting factors of plant production. This work aimed to evaluate the influences of irrigation frequency and soil salinity on the development of cactus pear cv. Miúda (Nopalea cochenillifera Salm Dyck). The experiment was conducted in factorial arrangement of four salinity levels: 0.3 (control), 0.5 (low), 1.5 (medium) and 3.6 (high salinity) (ds $\mathrm{m}^{-1}$ ), associated with four irrigation frequencies (each 7, 14, 21 and 28 days) and two soil textures (sandy and sandy loam) in a randomized block design with four replicates. One cladode was planted in each polyethylene pot containing $10 \mathrm{~kg}$ of soil. The soil texture influenced some of the morphological characteristics of the cactus pear, so that plants grown in sandy loam soil yielded higher number of cladodes (9.47) and higher productivity $\left(62.1 \mathrm{~g} \mathrm{plant}^{-1}\right)$. The sandy soil produced plants with fewer cladodes (4.50). Irrigation water with a salinity level of $3.6 \mathrm{ds} \mathrm{m}^{-1}$ and an irrigation frequency of 7 days showed higher soil electrical conductivity (48.65 $\mathrm{dS} \mathrm{\textrm {m } ^ { - 1 }}$ ) and plants with a higher damage (5.0) and lower productivity (32.51 $\left.\mathrm{g} \mathrm{plant}^{-1}\right)$, indicating a low tolerance of the cv. Miúda to salt stress.
\end{abstract}

Key words: cladodes, forage, salt stress, semiarid.

\section{INTRODUCTION}

Drought and salt tolerant alternate crops which can survive in adverse conditions are crucial for sustainability in arid and semiarid regions (Gajender et al. 2014). Semiarid areas occupy 60 to $65 \%$ of the total area in Northeastern Brazil. In these areas, it is common to use water from wells excavated near rivers, which are often unsuitable for irrigation,

Correspondence to: Mércia Virgínia F. dos Santos

E-mail: mercia.vfsantos@ufrpe.br contributing to the accumulation of salts in the soils. To use saline soils, it is necessary to improve the physiological characteristics of plants, adapting them to the environmental conditions, to avoid a decrease in productivity. According to Munns and Tester (2008), plant adaptation to the soil or plant improvement is feasible compared to the high costs of soil-recovery techniques.

The cactus pear (Opuntia and Nopalea) is one of the forage plants commonly grown in semiarid areas because it shows great water-use 
efficiency due to its CAM metabolism. The cactus pear has high digestibility; high levels of soluble carbohydrates, calcium and potassium; and low levels of dry matter and fiber; therefore, it is an important animal-feed alternative (Dubeux Jr. et al. 2010). The Nopalea cochenillifera Salm Dyck cv Miúda has a higher water requirement and is of great importance because it is resistant to carmine cochineal (Dactylopius opuntiae Cockerell), a pest that has caused losses in cactus pear plantations (Santos et al. 2010).

The cactus pear has low tolerance to salt stress, and its yield potential under irrigation conditions in Northeast Brazil is not known experimentally. Franco-Salazar and Veliz (2007), working with Opuntia ficus-indica Mill. in hydroponic culture with different concentrations of sodium chloride $(\mathrm{NaCl})$, observed that salinity affected the plant growth, reducing both the shoots and the roots. The cactus pear clones vary in adaptation to salinity conditions, and the productive performance of the cactus pear cv. Miúda is influenced by the soil salinity and the amount of irrigation (Freire 2012). Gajender et al. (2014) observed that Opuntia ficus indica Mill. was tolerant to moderate salinity (52 $\mathrm{mM}$ ) but sensitive to $\mathrm{pH}$ and had negligible growth at $\mathrm{pH} 9.8$.

The hypothesis was that cactus pear species differ in sensitivity to abiotic factors, which may affect growth, productivity and chemical composition. Thus, the aim of the present study was to evaluate the growth of the cactus pear cv. Miúda (Nopalea cochenillifera Salm Dyck) as a function of irrigation frequency, water salinity levels and soils with different textures.

\section{MATERIALS AND METHODS}

The experiment was conducted in a greenhouse at the Department of Animal Science of the Federal Rural University of Pernambuco - UFRPE.
The cactus pear cultivar used in the experiment was Miúda (Nopalea cochenillifera Salm Dyck), which originated from the Arcoverde Experimental Station of the Agronomic Institute of PernambucoIPA. Mature cladodes were used as planting material. The cladodes were removed from the intermediate portion of the plant, each weighing between 175 and $475 \mathrm{~g}$ (fresh weight). One cladode was planted in each polyethylene pot, containing $10 \mathrm{~kg}$ of soil with two different textures (sandy and sandy loam). Both soil types were collected in the municipality of São Bento do Una, which is located in the semiarid region of Pernambuco, Brazil.

Four salinity levels in the irrigation water were tested. These levels were defined according to the classification of Silva et al. (2011) as 0.3 (control), 0.5 (without restriction for use in irrigation), 1.5 (moderate restriction for use in irrigation) and 3.6 $\mathrm{dS} \mathrm{m}{ }^{-1}$ (severe restriction for use in irrigation), associated with four irrigation frequencies (each 7 , 14, 21, and 28 days) and two soil textures (sandy and sandy loam). The experimental design was a randomized block design in a factorial arrangement, with the initial weight of the cladodes used as the grouping criterion, with four replicates.

The electrical conductivity of the pure irrigation water was determined using a portable conductometer, resulting in a reading of $0.3 \mathrm{dS} \mathrm{m}^{-1}$. To determine the amount of sodium to add to the irrigation water for the three salinity levels to be tested, the electric conductivity of solutions with $0.25,0.5$ and $1 \mathrm{~g} / \mathrm{L} \mathrm{NaCl}$ (sodium chloride) in deionized water was read using a conductometer. After the reading, an equation was generated to identify the amount of $\mathrm{NaCl}$ to be added to the irrigation water.

The electrical conductivity of the soil was also determined at the beginning and end of the experiment. Initially, three samples from each soil were collected, and saturation pastes were prepared to obtain the extracts from which the electrical conductivity was measured, corresponding to 0.50 
and $0.86 \mathrm{dS} \mathrm{m}^{-1}$ for the sandy and sandy loam soils, respectively.

The chemical analyses of the irrigation water were carried out at the water chemical analysis laboratory in Recife-PE, obtaining the following values $4.49,0.25 \mathrm{dS} \mathrm{m}^{-1}, 0.02,0.13,0.02,2.14$ and $1.30 \mathrm{mmolc}^{-1}$ to $\mathrm{pH}, \mathrm{EC}, \mathrm{Ca}^{2+}, \mathrm{Mg}^{2+}, \mathrm{K}^{+}, \mathrm{Na}^{+}$ and $\mathrm{Cl}^{-}$, respectively. The chemical analysis of the soil was carried out in the soil fertility laboratory at UFRPE (Table I). Aiming to identify the texture of the experimental soil, the physical analyses were performed in the soil physics laboratory at IPA (Table I).

Each pot received a solution of soil micronutrients as described by Epstein and Bloom (2006) in an amount of $8 \mathrm{~mL}$ pot $^{-1}$. Nitrogen fertilization was performed using 33\% ammonium nitrate $\left(\mathrm{NH}_{4} \mathrm{NO}_{3}\right)$, applying $3 \mathrm{~g} \mathrm{~N}_{\text {pot }}{ }^{-1}$, which is equivalent to the application of $20 \mathrm{~mL} \mathrm{NH}_{4} \mathrm{NO}_{3}$ pot $^{-1}$. The amount of water applied in each pot was quantified according to the beginning of the drainage. At the end of the experiment, the sum of all of the water applied per soil type and per treatment during the experimental period was measured.

The plants were assessed to determine the cladode number, width, length, thickness of cladode and productivity. To measure the width and length, a measuring tape was used, and the thickness was measured with a caliper rule. To assess the damage of the plants, a scale ranging from 1 to 5 was used, and the entire plant and cladodes were evaluated individually every 14 days; cladodes showing dehydration and yellowish coloration were considered to be damaged. The rating scale used to assess the damage was 1,2, 3, 4 and 5 to 0.1-25, 26-50, 51-75 and 76-100\%, respectively.

Plant harvesting was performed on July 20, 2010, 225 days after the application of treatments, at the time when all of the plants from the same treatment in all of the blocks showed $100 \%$ damage.

The analysis of variance was performed using the Proc mixed procedure of the SAS Software, and the experimental treatment means, when significant, were compared using Tukey's test at 5\% probability. Subsequently, regression analysis, at $5 \%$ probability, was performed with the SigmaPlot version 12.0 software.

\section{RESULTS}

There were significant differences between the soil types and irrigation frequencies for the total water supplied to the plants $(p<0.05)$. The total amount of water was higher when using the irrigation frequency of 7 days for both of the soils under study (Table II). With the irrigation frequency of 7 days, the pots received, on average, $32 \mathrm{~L}$ of water by the

TABLE I

Chemical and physical characterization of the soils used in the experiment.

\begin{tabular}{|c|c|c|c|c|c|c|c|c|c|}
\hline \multirow{3}{*}{ Soils } & \multicolumn{9}{|c|}{ Chemical characterization } \\
\hline & $\mathrm{pH}$ & $* \mathbf{P}$ & $\mathrm{Na}^{+}$ & $\mathbf{K}^{+}$ & $* * \mathrm{Ca}^{2+}$ & $\mathrm{Mg}^{2+}$ & $* * \mathbf{A l}^{3+}$ & $* * * \mathbf{H}+\mathbf{A l}$ & OM \\
\hline & \multicolumn{4}{|c|}{$\mathrm{g} \mathrm{dm}^{-3}$} & \multicolumn{4}{|c|}{$-c m o l c d^{-3}--$} & $\mathrm{g} \mathrm{kg}^{-1}$ \\
\hline Sandy & 4.95 & 80 & 0.26 & 1.05 & 1.20 & 0.90 & 0.15 & 3.11 & 23.73 \\
\hline \multirow[t]{3}{*}{ Sandy loam } & 5.85 & 180 & 1.09 & 2.51 & 3.60 & 2.70 & 0.00 & 3.73 & 31.70 \\
\hline & \multicolumn{9}{|c|}{ Physical characterization } \\
\hline & \multicolumn{2}{|c|}{$\begin{array}{l}\text { Soil density } \\
\mathrm{g} \mathrm{cm}^{-3}\end{array}$} & \multicolumn{2}{|c|}{ Particle density } & \multicolumn{2}{|c|}{ Coarse sand } & Fine sand & Silt & Clay \\
\hline Sandy & \multicolumn{2}{|c|}{1.74} & \multicolumn{2}{|c|}{2.65} & \multicolumn{2}{|c|}{68} & 16 & 10 & 6 \\
\hline Sandy loam & \multicolumn{2}{|c|}{1.50} & \multicolumn{2}{|c|}{2.65} & \multicolumn{2}{|c|}{43} & 21 & 22 & 14 \\
\hline
\end{tabular}


end of the experiment. At the irrigation frequencies of 7, 14 and 28 days, no differences were observed between the soils, while at the frequency of 21 days, the amount of water was higher in the sandy loam soil.

There were significant effects $(p<0.05)$ of the interaction between the salinity levels and irrigation frequencies (Figure 1) and between the soil types and irrigation frequencies for the soil electrical conductivity (Table III).

There was no significant effect of the factors studied for the length of cladodes. There was a

\section{TABLE II}

Total water (L) supplied to the cactus pear plants during the experiment according to the soil types and irrigation frequency.

\begin{tabular}{ccc}
\hline \multirow{2}{*}{ Irrigation frequency (days) } & \multicolumn{2}{c}{ Soils } \\
\cline { 2 - 3 } & Sandy loam & Sandy \\
\hline 7 & $32.125 \mathrm{aA}$ & $32.660 \mathrm{aA}$ \\
14 & $17.433 \mathrm{aB}$ & $17.790 \mathrm{aB}$ \\
21 & $14.135 \mathrm{aC}$ & $11.885 \mathrm{bC}$ \\
28 & $8.543 \mathrm{aD}$ & $8.645 \mathrm{aD}$ \\
$\mathrm{CV}(\%)$ & \multicolumn{2}{c}{2.94} \\
\hline
\end{tabular}

Means followed by different letters (lowercase in the row and uppercase in the column) differ statistically $(p<0.05)$ based on F and Tukey's test, respectively.

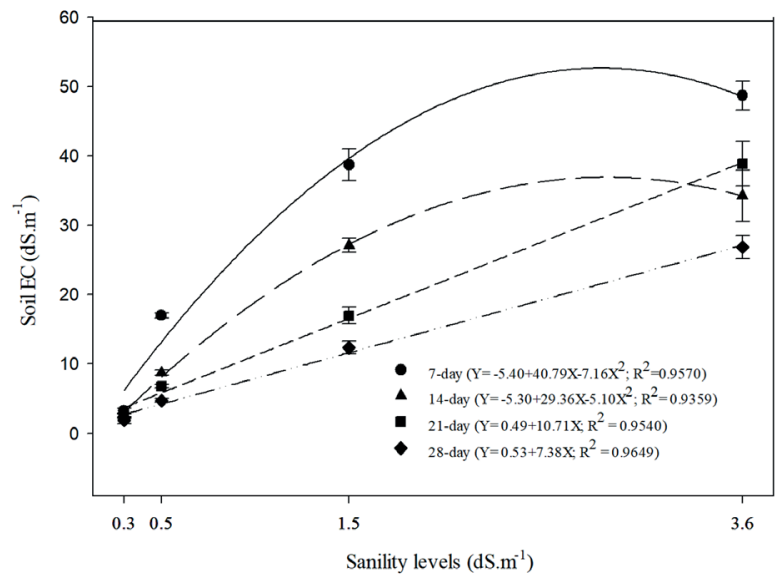

Figure 1 - Electrical conductivity (EC) of the soil grown by cactus pear cv. Miúda according to the irrigation frequencies (7-day: line solid; 14-day: line long dash; 21-day: line short dash and 28-day: line dash-dot-dot) and salinity levels. Error bars represent the standard error of the mean. significant $(p<0.05)$ decrease in the cladodes width as a function of the salinity level of the irrigation water (Figure 2). Regarding cladode thickness (Figure 3), there was a triple interaction among the factors of salinity level, irrigation frequency and soil type $(p<0.05)$.

There was a significant effect $(p<0.05)$ of the interaction between the irrigation frequency and soil types on the number of cladodes per plant (Table III). There was also a significant difference in the number of cladodes due to the salinity level (Figure 4). In the sandy loam soil, there were plants with more cladodes at the irrigation frequency of 21 days, with significant differences $(p<0.05)$ between the plants grown in sandy loam soil and sandy soil.

A significant effect $(p<0.05)$ was observed between the salinity levels and cladode order on the variable 'plant damage' (Figure 5). For all of the cladode orders (basal, primary and secondary), the greatest damage occurred at the salinity level of 1.5 and $3.6 \mathrm{dS} \mathrm{m}^{-1}$ while the major damages occurred in the secondary cladodes.

A significant effect $(p<0.05)$ was observed on dry matter yield in the interaction between the irrigation frequency and soil type as well as the interaction between the salinity levels and

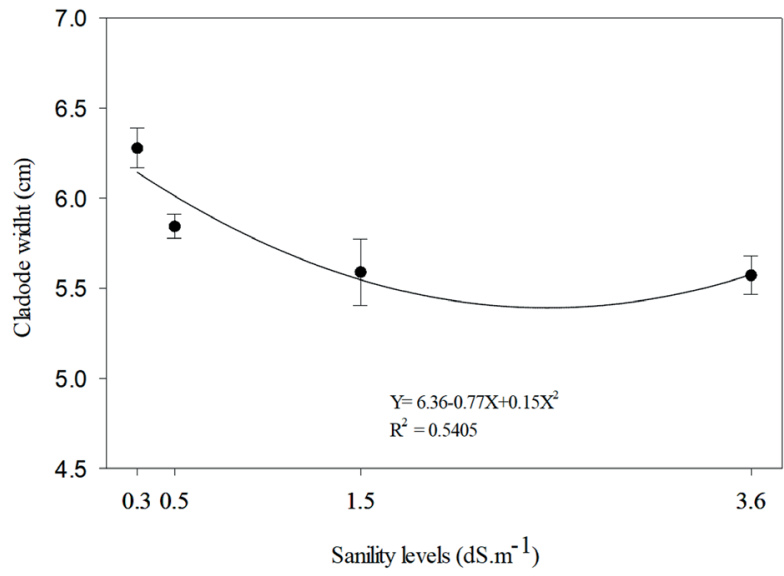

Figure 2 - Cladode width of cactus pear cv. Miúda according to the salinity levels of water irrigation. Error bars represent the standard error of the mean. 
TABLE III

Soil electrical conductivity $\left(\mathrm{dS} \mathrm{m} \mathrm{m}^{-1}\right)$, number of cladodes and dry-matter yield ( $\left.\mathrm{g} \mathrm{plant}^{-1}\right)$ of cactus pear cv. Miúda according to the irrigation frequency and soil types.

\begin{tabular}{|c|c|c|c|c|}
\hline \multirow{3}{*}{ Soils } & \multicolumn{4}{|c|}{ Irrigation frequency (days) } \\
\hline & 7 & 14 & 21 & 28 \\
\hline & \multicolumn{4}{|c|}{ Soil electrical conductivity $\left(\mathrm{dS} \mathrm{m}^{-1}\right)$} \\
\hline Sandy loam & $26.88 \mathrm{aA}$ & $18.47 \mathrm{bA}$ & $17.76 \mathrm{bA}$ & $10.80 \mathrm{cA}$ \\
\hline Sandy & $28.03 \mathrm{aA}$ & $18.27 \mathrm{bA}$ & $14.82 \mathrm{cB}$ & $12.05 \mathrm{dA}$ \\
\hline \multirow[t]{2}{*}{$\mathrm{CV}(\%)$} & \multicolumn{4}{|c|}{5.79} \\
\hline & \multicolumn{4}{|c|}{ Number of cladodes } \\
\hline Sandy loam & $7.36 \mathrm{bA}$ & $8.59 \mathrm{abA}$ & $9.47 \mathrm{aA}$ & $7.25 \mathrm{bA}$ \\
\hline Sandy & $5.93 \mathrm{aA}$ & $5.18 \mathrm{aB}$ & $4.56 \mathrm{aB}$ & $4.50 \mathrm{bB}$ \\
\hline \multirow[t]{2}{*}{$\mathrm{CV}(\%)$} & & 7.99 & & \\
\hline & \multicolumn{4}{|c|}{ Dry-matter yield (g plant ${ }^{-1}$ ) } \\
\hline Sandy loam & $62.1 \mathrm{aA}$ & $52.3 \mathrm{bA}$ & $56.2 \mathrm{bA}$ & $47.1 \mathrm{cA}$ \\
\hline Sandy & $52.4 \mathrm{aB}$ & $50.3 \mathrm{aA}$ & $43.8 \mathrm{bB}$ & $34.3 \mathrm{cB}$ \\
\hline $\mathrm{CV}(\%)$ & & 12.35 & & \\
\hline
\end{tabular}

Means followed by different letters (lowercase in the row and uppercase in the column) differ statistically $(p<0.05)$ based on $\mathrm{F}$ and Tukey's test.

irrigation frequency (Figure 6). Plants with higher productivity were observed in the sandy soils, but in the loam sandy soils was observed the presence of higher amounts of $\mathrm{P}, \mathrm{K}$ and organic matter (OM) in the soil (Table I).

For dry matter production by cactus pear $\mathrm{cv}$. Miúda, a significant interaction $(p<0.05)$ was observed between the irrigation frequency and salinity levels. The lowest salinity level $\left(0.3 \mathrm{dS} \mathrm{m}^{-1}\right)$ of the irrigation water and the irrigation frequency of 7 days favored higher DM yield (Figure 6), while the salinity levels of $0.5,1.5$ and $3.6 \mathrm{dS} \mathrm{m}^{-1}$ damaged the production of cactus pear cv. Miúda.

\section{DISCUSSION}

The soil type and irrigation frequency significantly affected the total amount of water supplied to the plants (Table II). High sodium concentrations in the soil, in addition to directly harming the plants, degrade the plant structure and decrease soil porosity and permeability (Munns 2017).

The treatments with high salinity level provided high soil conductivity. This effect was more pronounced with higher irrigation frequencies, caused by the greater amount of water received and consequently higher ion deposition in the soils. The irrigation frequency of 28 days provided lower soil electrical conductivity values (Table III), resulting from the lower amounts of water received by the plants during this period (Table II).

According to Munns and Tester (2008), the limit of soil electrical conductivity for the growth of most plant species is $7.0 \mathrm{dS} \mathrm{m}^{-1}$, which occurred, in the present study, due to the treatment with 0.5 $\mathrm{dS} \mathrm{m}{ }^{-1}$. It is noteworthy that soils with electrical conductivity of 4-7 $\mathrm{ds} \mathrm{m}^{-1}$ in areas grown cactus pear results in a system of low sustainability, according to Inglese et al. (2017).

Tabosa et al. (2007), working with sorghum genotypes under salt stress in a greenhouse, found salinity levels of the soil saturation extract between 15 and $30 \mathrm{dS} \mathrm{m}^{-1}$, depending on the amount of salt present in the irrigation water and the soil. According to Pedrotill et al. (2015), excess of sodium salts in the soil affects soil physical and chemical properties, reducing the porosity and 

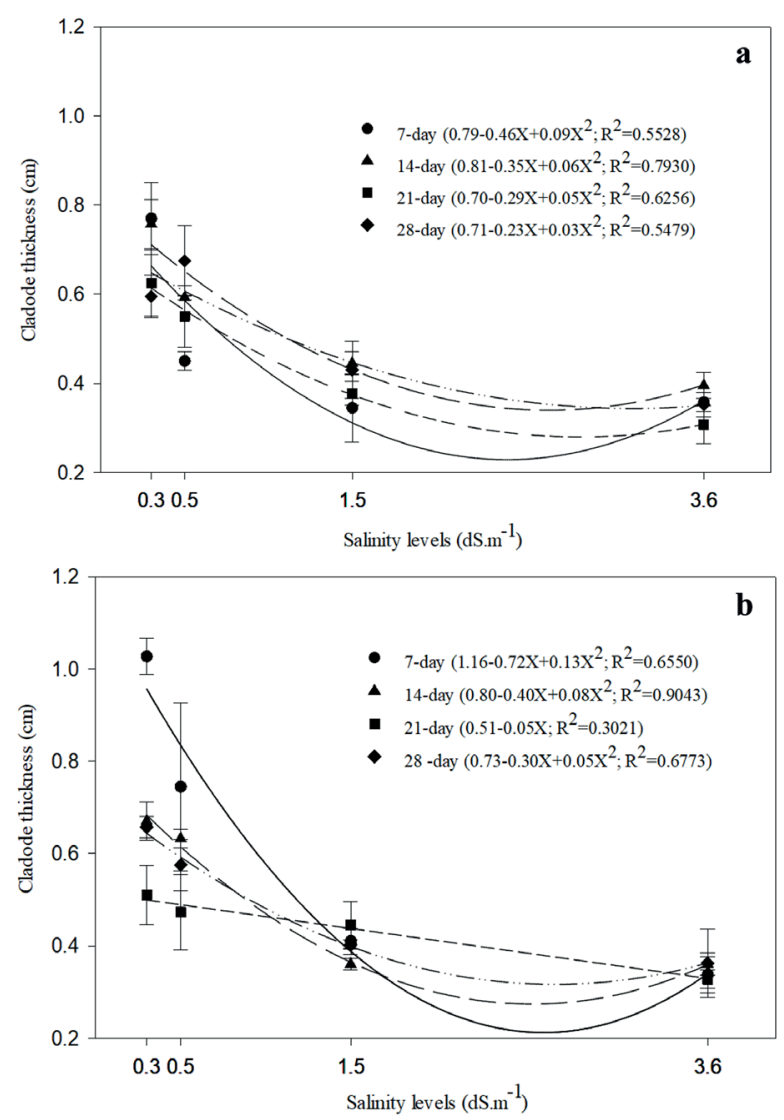

Figure 3 - Cladode thickness $(\mathrm{cm})$ of cactus pear cv. Miúda according to the irrigation frequency, salinity level (7-day: line solid; 14-day: line long dash; 21-day: line short dash and 28day: line dash-dot-dot) and soil type (a: Sandy and b: Sandy loam). Error bars represent the standard error of the mean.

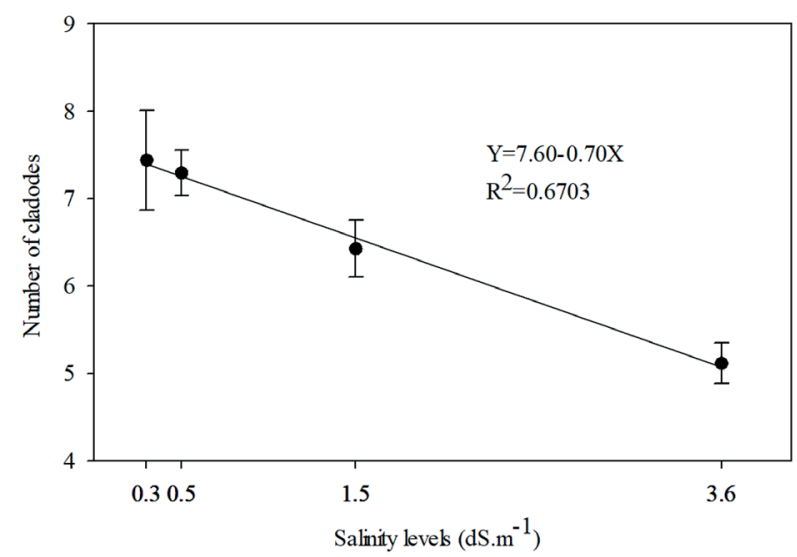

Figure 4 - Number of cladodes from cactus pear cv. Miúda according to the salinity levels. Error bars represent the standard error of the mean.

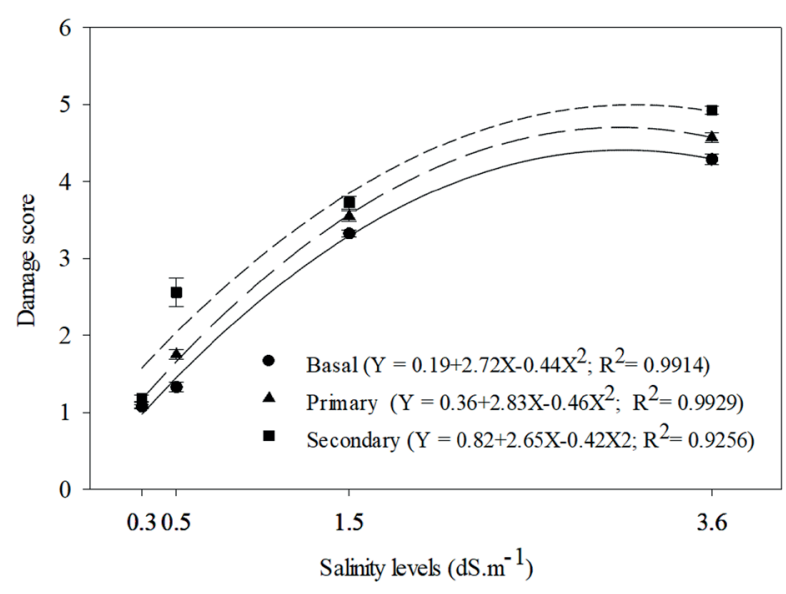

Figure 5 - Damage score of cactus pear cv. Miúda according to the salinity levels and cladode order (basal: line solid; primary: line long dash and secondary: line short dash). Error bars represent the standard error of the mean.

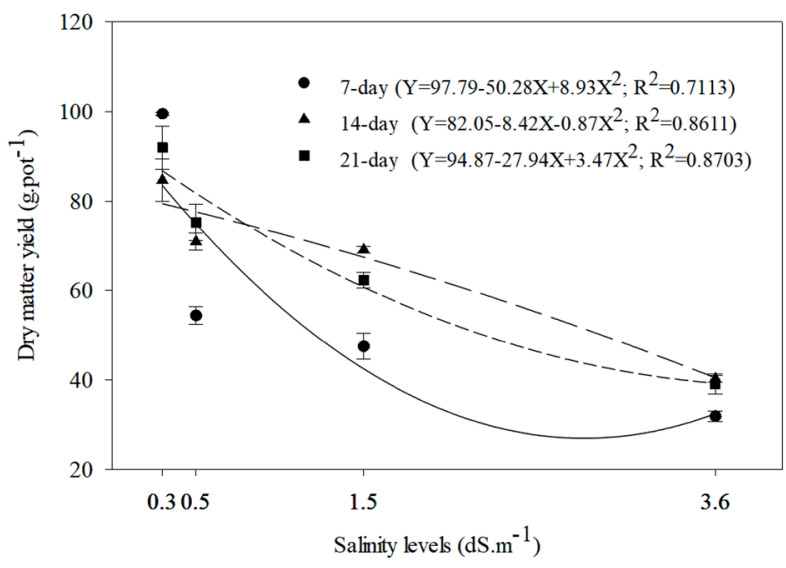

Figure 6 - Dry-matter yield of the cactus pear cv. Miúda according to the salinity levels and irrigation frequency (7-day: line solid; 14-day: line long dash and 21-day: line short dash). Error bars represent the standard error of the mean.

permeability of the soil. The presence of sodium salts in the soil causes an increase in electrical conductivity, resulting in an overall reduction of the growth of cultivated plants, with extensive damage to agriculture (Munns 2017).

The sandy soil produced plants with fewer cladodes (Table III), which is most likely associated with the lower amount of organic matter (OM), $\mathrm{P}$ and $\mathrm{K}$ that this type of soil presented compared to the sandy loam soil (Table I). A salinity level of $3.6 \mathrm{dS} \mathrm{m}^{-1}$ in the irrigation water resulted in fewer 
cladodes compared to other salinity levels, most likely due to the greater amount of salt absorbed by the plants. According to Coelho et al. (2013), there was a decrease in plant height, number of leaves and dry biomass at an electrical conductivity of the soil saturation extract between 4 and $12 \mathrm{dS} \mathrm{m}^{-1}$.

The salinity level of $0.3 \mathrm{dS} \mathrm{m}^{-1}$ resulted in greater cladode width (Figure 2), while the level of $3.6 \mathrm{dS} \mathrm{m}^{-1}$ resulted in lower width, indicating that a high level of water salinity is detrimental to the growth of cladodes of cactus pear.

Less frequent irrigation led to a decrease in the thickness (Figure 3) of cladodes in both of the soil types. The higher water salinity levels resulted in lower cladode thickness, most likely due to water stress and excess salts in the soil and plants, causing dehydration of the cladodes. The cladode thickness was most likely related to the amount of water present in the cladodes, consequently, higher water salt levels and lower irrigation frequencies resulted in lower cladode thickness. Silva-Ortega et al. (2008) observed that the treatment with $\mathrm{NaCl}$ of $O$. streptacantha young plants resulted in a decrease in the cladode thickness and root length. According to Inglese et al. (2017), diel fluctuations in cladode thickness may also represent an early indicator of dehydration stress. Young cladodes show more pronounced diel thickness fluctuations compared with older cladodes, and therefore serve as a suitable model for assessing plant responses to environmental factors.

For all of the cladode orders (basal, primary and secondary), the greatest damage occurred at the salinity level of 1.5 and $3.6 \mathrm{dS} \mathrm{m}^{-1}$ (Figure 5). The secondary cladodes showed higher grades of damage, indicating that the symptoms of chlorosis and dehydration occur primarily in younger cladodes until the basal cladode is reached.

The lowest salinity level of the irrigation water (Figure 6) and the irrigation frequency of 7 days (Table III) favored higher DM yield, while the salinity levels of $0.5,1.5$ and $3.6 \mathrm{dS} \mathrm{m}^{-1}$ impaired the production of cactus pear cv. Miúda. Gajender et al. (2014) reported that the adverse effect of soil salinity and alkalinity could be moderated with application of fertilization. Dubeux Jr. et al. (2010), working with IPA-20 clone of cactus fertilized and irrigated in a greenhouse, observed higher yields of up to $100 \mathrm{~g} \mathrm{pot}^{-1}$ when using equivalent to 200 and $800 \mathrm{~kg} / \mathrm{ha}$ of $\mathrm{P}_{2} \mathrm{O}_{5}$ and $\mathrm{K}_{2} \mathrm{O}$ fertilization, respectively. Souza et al. (2017), working with Nopalea, observed that productivity was influenced by site, in both sites was classified as Entisol.

For suitable use of different semi-arid areas, it is essential to know the proportion of productivity reduction of cactus pear grown under salinity conditions. According to Inglese et al. (2017), generally, Opuntia ficus-indica is very versatile, but it is sensitive to high salinity and waterlogging, since its root system is very sensitive to anoxia. Reports on the growth of the cultivar Miúda in conditions of salinity are scarce. However, considering the greater water requirement of this cultivar, in relation to the others, probably the negative effects of the high salinity in the development of cactus pear should occur at an earlier stage. Researches are needed to study the effect of salinity on plants irrigated with saline water and, according to Dubeux Jr. et al. (2017), application of small amounts of saline water and use of organic fertilizer reduces any potential problem of soil salinization.

\section{CONCLUSIONS}

The sandy soils resulted in cactus pear cv Miúda with a higher number of cladodes and higher productivity.

A water salinity of $3.6 \mathrm{dS} \mathrm{m}$ and an irrigation frequency of 7 days resulted in greater soil electrical conductivity and a higher percentage of damage and lower productivity of cactus pear cv Miúda, suggesting high sensitivity of this species to salt stress. 


\section{ACKNOWLEDGMENTS}

We thank the support provided by the Conselho Nacional de Desenvolvimento Científico e Tecnológico (CNPq) and Fundação de Amparo à Ciência e Tecnologia de Pernambuco (FACEPE), Brazil. This study was financed in part by the Coordenação de Aperfeiçoamento de Pessoal de Nível Superior - Brasil (CAPES) - Finance Code 001 .

\section{REFERENCES}

COELHO JBM, BARROS MFC, BEZERRA NETO E AND COELHO MM. 2013. Comportamento hídrico e crescimento do feijão vigna cultivado em solos salinizados. Rev Bras Eng Agric Ambient 17: 379-385.

DUBEUX JR JCB, ARAUJO FILHO JT, SANTOS MVF, LIRA MA, SANTOS DC AND PESSOA RAS. 2010. Adubação mineral no crescimento e composição mineral da palma forrageira - clone IPA-20. Rev Bras Ciênc Agrár 5: 129-135.

DUBEUX JR JCB, BEM SALEM H AND NEFZAOUI A. 2017. Forage production and supply for animal nutrition. In: Inglese $\mathrm{P}$ et al. (Eds), Crop ecology, cultivation and uses of cactus pear crop ecology, cultivation. Food and Agriculture Organization of the United Nations and the International Center for Agricultural Research in the Dry Areas Rome, p.73-92.

EPSTEIN E AND BLOOM AJ. 2006. Nutrição mineral de plantas: princípios e perspectivas. $2^{\mathrm{a}}$ ed., Londrina: Planta, $404 \mathrm{p}$.

FRANCO-SALAZAR VA AND VELIZ JA. 2007. Respostas de La tuna (Opuntia fícus-indica (I) Mill) al NaCl. Interciencia 32: 125-130.

FREIRE JL. 2012. Avaliação de clones de palma forrageira (Opuntia e Napolea) sob irrigação e salinidade. Universidade Federal Rural de Pernambuco, RecifePE, Brasil. Disponível em https://ppgzufrpe.jimdo. com/app/download/9183534471/joelma de lira freire. pdf?t=1432556604. (Acessado em Novembro 2017).

GAJENDER GS, DAGAR JC, LAL K AND YADAV RK. 2014. Performance of edible cactus (Opuntia ficus-indica) in saline environments. Indian J Agr Sci 84: 509-513.

INGLESE P, LIGUORI G AND BARRERA E. 2017. Ecophysiology and reproductive biology of cultivated cacti. In: Inglese P et al. (Eds), Crop ecology, cultivation and uses of cactus pear crop ecology, cultivation. Food and Agriculture Organization of the United Nations and the International Center for Agricultural Research in the Dry Areas Rome, p. 43-50.

MUNNS R. 2017. The impact of salinity stress. Available at: http://www.plantstress.com/Articles/salinity_i/salinity_i. htm. (accessed November 2017).

MUNNS R AND TESTER M. 2008. Mechanisms of salinity tolerance. Annu Rev Plant Biol 59: 651-681.

PEDROTTIL A, CHAGAS RM, RAMOS VC, PRATA APN, LUCAS AAT AND SANTOS PB. 2015. Causas e consequências do processo de salinização dos solos. REGET 19: 1308-1324.

SANTOS MVF, LIRA MA, DUBEUX JR JCB, FERREIRA MA AND CUNHA MV. 2010. Palma forrageira. In: Fonseca DM and Martuscello JA(Eds), Plantas forrageiras. Universidade Federal de Viçosa, Viçosa, Mina Gerais, Brasil, p. 204-215.

SILVA IN, FONTES LO, TAVELLA LB, OLIVEIRA JB AND OLIVEIRA AC. 2011. Qualidade de água na irrigação. ACSA 7: 1-15.

SILVA-ORTEGA CO, OCHOA-ALFARO AE, REYESAGUERO JA, AGUADO-SANTACRUZ GA AND JIMÉNEZ-BREMONT JF. 2008. Salt stress increases the expression of $\mathrm{p} 5 \mathrm{cs}$ gene and induces proline accumulation in cactus pear. Plant Physiol Biochem 46: 82-92.

SOUZA TC, SANTOS MVF, DUBEUX JÚNIOR JCB, LIRA MA, SANTOS DC, CUNHA MV, LIMA LE AND SILVA RR. 2017. Productivity and nutrient concentration in spineless cactus under different fertilizations and plant densities. Rev Bras Ciênc Agrár 12: 555-560.

TABOSA JN, COLAÇO W, REIS OV, SIMPLICIO JB AND DIAS FM. 2007. Sorghum genotypes evaluation under salinity levels and gamma ray doses. Rev Bras de Milho e Sorgo 6: 339-350. 